\title{
NARRACJE O PRZYSZŁOŚCI A PROJEKTOWANIE INNOWACJI - PERSPEKTYWA STUDIÓW NAD NAUKĄ I TECHNOLOGIĄ
}

Agata Stasik

Akademia Leona Koźmińskiego

Stosowanie nowych technologii od bardzo dawna współtworzyło ludzkie społeczeństwo - z planetarną skalą konsekwencji rewolucyjnego pomysłu uprawy ziemi równać się moga jedynie konsekwencje spalania paliw kopalnych. Dziś jednak powszechne zdaje się odczucie, że rozwój technologiczny jest szybszy niż kiedykolwiek, a jego wpływ bardziej wszechogarniający: składane obietnice zapieraja dech w piersiach (por. Harari 2018). Słyszymy o miastach przekształconych przez samobieżne pojazdy, lotach na Marsa, rozwoju sztucznej inteligencji, leczeniu przez nanoroboty, mięsie z próbówek. Zaprojektowane i udomowione dziś technologie będą współkształtowały nasza przyszłość - wpłyną też na przyszłe pokolenia i inne gatunki. Jednak fakt, że dzisiejsze wybory wpłyną na wspólną przyszłość, to tylko część opowieści, być może bardziej oczywista. Nie mniej ważna jest konstatacja, że dzisiejsze (wyobrażania) przyszłości wpływają na to, w jakie rozwiązania decydujemy się inwestować wspólne zasoby. Przyszłość jest nie tylko pustą kartą, którą zapisujemy dzisiejszymi wyborami. Poruszamy się wśród wizji przyszłości wyrażanych w rozmaitych formach: od poetyckiego proroctwa, fantastyki naukowej i publicystyki, przez raporty firm naftowych, po państwowe programy badawcze, decyzje inwestycyjne funduszy emerytalnych i funduszy wysokiego ryzyka. Opowieści o możliwych i prawdopodobnych przyszłościach w całej ich różnorodności są

${ }^{1}$ Praca nad artykułem była wspierana przez Narodowe Centrum Nauki (Grant DEC-2014/15/N/ HS4/01413). 
kluczowym zasobem wytwarzanym i mobilizowanym do tego, by utrudnić lub zablokować pewne działania, a umożliwić inne.

Obserwujemy zatem zarówno oddziaływanie dzisiejszych wyborów na kształt przyszłości, jak i oddziaływanie podzielanych (wyobrażeń) przyszłości na dzisiejsze wybory. Ten dwukierunkowy wpływ nigdzie nie jest tak intrygujący, jak na polu nauki i technologii. Badanie naukowe i majsterkowanie przy nowych rozwiązaniach technologicznych zawsze zaczyna się od obietnicy, nadziei, propozycji wystarczająco kuszącej, by zmobilizować badaczkę i jej sojuszników (por. Konrad i in. 2017: 471). Dziś składamy społeczeństwu obietnice między innymi w części wniosku grantowego „Spodziewane rezultaty”, ale i w przeszłości nadzieja na ustalenie faktu lub stworzenie działającego artefaktu była niezbędnym składnikiem wysiłku badacza. Znakomicie ilustruje to cytowany przez Bruno Latoura (2013: 40-41) list Ludwika Pasteura do Ministra Edukacji Publicznej, w której badacz, zabiegając o środki na badanie roślin zarodnikowych i ich roli $\mathrm{w}$ procesie fermentacji, przywołuje potencjał eksportowy francuskiego wina. Pasteur przedstawia więc wizję, w której powodzenie badań jest niezbędnym krokiem we wspólnym zmierzaniu do realizacji określonej wizji przyszłości: tej, w której francuskie wino eksportuje się na potęgę. Dzięki temu ustanawia siebie jako obowiązkowy punkt przejścia, przynajmniej tymczasowo zabezpieczając współpracę z niezbędnymi sojusznikami (por. Callon 2014a). Robimy to za każdym razem: nie da się przecież prowadzić badań, nie oferując innym aktorom określonych przyszłości.

Jednak przyszłości, które rządzą badaniami, to nie tylko konkretne oczekiwane rezultaty. Nie mniej ważna jest wielka wizja, która łączy wytwarzanie kolejnych faktów i bytów z rosnącym powodzeniem zbiorowości²: przekonanie, że rozwój naukowy i technologiczny przynosi zmianę na lepsze. Rozpoznanie, że wyobrażanie sobie pożądanej przyszłości jest kluczowym krokiem w wytwarzaniu nowej wiedzy i - szczególnie - nowych rozwiązań technologicznych, znajdujemy u źródeł nowoczesnej nauki; nie przypadkiem Francis Bacon, namawiając do rozwoju nauk i technologii, stworzył wizję Nowej Atlantydy (Wewiór 2017). Najbardziej instrumentalne, skuteczne, przyziemne rozwiązania nie są wyłącznie wytworem zimnej racjonalności - są również zależne od wizji, utopii, wyobraźni czy inspiracji religijnej.

Skupienie uwagi na dwustronnej zależności pomiędzy przyszłościami a wytwarzaniem nowych technologii prowadzi do podjęcia kwestii od-

${ }^{2}$ Pojęcia zbiorowości (ang. collective) używam za Bruno Latourem (por. np. Latour 2010) w znaczeniu społeczeństwa poszerzonego o czynniki pozaludzkie. 
powiedzialności - politycznej, etycznej i społecznej - związanej z wprowadzaniem nowych rozwiązań technologicznych, ale też rozwijaniem określonych narracji o przyszłości. Tradycyjnie, pomimo wpływu wyborów technologicznych na życie zbiorowości, proces tworzenia technologii rozumiany jest jako oddzielony od tego, co polityczne i społeczne, wyjaśniany przez determinizm technologiczny i ekonomiczny, redukowany do nieuchronnego następstwa globalnych zmagań o konkurencyjność (krytyka, por. Latour 2011, Jasanoff 2004). Tymczasem podjęcie próby troski o przyszłość wymaga włączenia procesu wytwarzania nowych rozwiązań technologicznych i nowej wiedzy do domeny kultury, polityki, tożsamości, a więc domeny wspólnych wyborów (por. Bińczyk 2012, cz. V). Wymaga to przemyślenia procesów tworzenia narracji o przyszłościach i ich roli w wytwarzanych faktach naukowych i rozwiązaniach technologicznych. Z pomoca przychodzą tu studia nad nauką i technologia (STS), proponując perspektywę, w ramach której tworzenie innowacji jest zaplątane w to, co społeczne, tak że nie sposób powiedzieć, gdzie przebiega granica pomiędzy tymi domenami (Latour 1987, Jasanoff 2004, Abriszewski 2008). Celem artykułu jest przeanalizowanie wkładu studiów nad nauką $i$ technologią w debatę o dwustronnej zależności pomiędzy wytwarzaniem wiedzy i technologii a przyszłościami społecznymi i dzisiejszymi wyobrażeniami o możliwych przyszłościach.

\section{/// Studia nad nauką i technologią a narracje o przyszłości}

Przy całej różnorodności rozwijanych perspektyw i badanych przypadków za wspólny mianownik studiów nad nauką i technologią uznać można założenie, że wytwarzanie wiedzy i technologii jest nierozerwalnie związane ze sposobem życia zbiorowości (Jasanoff 2004: 2). W ramach teorii aktora-sieci (ang. Actor-Network Theory, ANT), jednej z najważniejszych perspektyw w ramach STS, podkreśla się ponadto, że choć w naszych praktykach dyskursywnych i instytucjonalnych oddzielamy porządek natury od porządku polityki, to jednak to fundamentalne dla naszego pojmowania nowoczesności oddzielenie jest złudne: zmiana po stronie tego, co „naturalne" i ,nie-ludzkie", jest możliwa tylko dzięki zmianom i przesunięciom po stronie tego, co społeczne (Latour 2011, Callon 2014a). Jednym ze sposobów opisania tego procesu jest wprowadzenie pojęcia ontologii relacyjnej (Latour 2013: 35, por. Abriszewski 2008), w myśl której dołączenie nowego elementu do sieci jest możliwe tylko dzięki temu, że zmienia/wpływa on na inne elementy. Praktycznym postulatem wynikającym z tych rozważań jest 
specyficznie rozumiane upolitycznienie procesu tworzenia nauki i technologii. Inaczej niż w języku potocznym, upolitycznienie oznacza tu nie poddanie naukowców presji potężnych interesów i ideologii, ale ujawnienie (istniejącego już dziś) politycznego (czy też wspólnototwórczego) aspektu tych procesów i poszukiwanie sposobu na to, by różnorodne grupy, tożsamości i interesy były w nim odpowiednio reprezentowane (Latour 2004, 2005, por. Bińczyk 2007).

Jednak obok wpływowego nurtu STS, zajętego śledzeniem powstania faktów u samych korzeni, istnieje również drugi nurt, bardziej pragmatyczny i z mniejszymi ambicjami filozoficznymi, skupiony przede wszystkim na tym, w jaki sposób nauka i technologia, rozumiana jako część życia społecznego, może stać się w większym stopniu przedmiotem publicznej debaty i decyzji. Fuller (2000), nawiązując do historii reformacji, określił te dwa nurty jako przedstawicieli „wysokiego” i „niskiego Kościoła” (Sismondo 2008: 18-19). Ten praktyczny nurt wyrasta ze współpracy z inżynierami, przedstawicielami nauk przyrodniczych i ścisłych czy urzędnikami i politykami odpowiedzialnymi za podejmowanie decyzji. Jednak pomimo odmiennych metod badawczych i retoryki, a do pewnego stopnia również odmiennych sposobów instytucjonalizacji w ramach $\mathrm{Akademii}^{3}$, wezwanie do poszukiwania sposobów na bardziej włączający i refleksyjny sposób podejmowania decyzji dotyczących technologii łączy te nurty.

Obydwie „szkoły” STS stoja zatem w opozycji nie tylko wobec rozumienia rozwoju technologii przez pryzmat determinizmu technologicznego i ekonomicznego, ale też wobec żywej tradycji obrony autonomii nauki, reprezentowanej między innymi przez Michaela Polanyiego. W myśl tej tradycji, skoro nauka jest nieprzewidywalna, jest również niemożliwa do zarządzenia - i należy jej pozwolić taka pozostać, ponieważ dzięki oddzieleniu od chaosu tego, co społeczne, najlepiej służy społeczeństwu. Trudność przewidywania dotyczy szczególnie wpływu nowej wiedzy i nowych technologii na procesy społeczne, ponieważ wymaga to uwzględnienia szeregu czynników pozostających w złożonych relacjach, co przekracza możliwości nauki.

Jak zatem realizować rewolucyjny postulat: no innovation without representation! (Latour 2004: 17)? Jak wyglądać mają zadawalające formy reprezentacji, które pozwolą uwzględnić głos społeczeństwa, ale nie skończą się źle

\footnotetext{
${ }^{3}$ W świecie anglosaskim „Wysoki Kościół” często instytucjonalizuje się (w formie wydziałów, czasopism czy grup badawczych) pod szyldem „Science and Technology Studies”, podczas gdy „Niski Kościól” - „Science, Technology and Society” (Sismondo 2008: 18). Szczęśliwym zbiegiem okoliczności obie nazwy mają ten sam akronim.
} 
pojmowanym upolitycznieniem nauki? Jedną z jej form może być wypracowanie włączających mechanizmów antycypacji - wspólnego wytwarzania społeczno-technologicznych wizji przyszłości. Żeby jednak proponować takie rozwiązania, należy przemyśleć kwestie wpływu wizji przyszłości na kierunek rozwoju technologii.

\section{/// Sprawczość przyszłości: oczekiwania, wizje, wyobrażenia}

W jaki sposób scenariusze, obietnice, prognozy dotyczące nauki i technologii wpływają na dynamikę powstawania odkryć i wynalazków? Kornelia Konrad i współautorzy (2017: 465-494), podsumowując ustalenia STS, proponują rozważenie performatywności wizji przyszłości w kontekście rozwoju technologii na trzech poziomach: jako oczekiwań, wizji i wyobrażeń społeczno-technologicznych.

Badanie oczekiwań (ang. expectations) w ramach ,socjologii oczekiwań” (Borup i in. 2006) opiera się na założeniu, że oczekiwania dotyczące technologii są zbiorowe (są właściwością społeczności) i można badać ich publiczne reprezentacje. Konrad i współautorzy rozumieja je jako stwierdzenia o przyszłym stanie rzeczy, zawierające ocenę jego prawdopodobieństwa, dostępne w społeczności lub w sferze publicznej (2017: 466). Dzięki temu, że oczekiwania są do pewnego stopnia podzielane przez przedstawicieli różnych grup, umożliwiają koordynację działań pomiędzy aktorami, domenami i skalami, czasami odległymi i rządzącymi się różnymi regułami (Borup i in. 2006: 286, Konrad i in. 2017: 466-467); w języku teoretycznym ANT możemy powiedzieć, że ułatwiają translację i werbunek sojuszników. Najbardziej oczywistą korzyścią wynikającą z działania w myśl oczekiwań jest możliwość pozyskania środków finansowych na badania czy innowacje, czy to z instytucji publicznych, czy też od inwestorów prywatnych. $\mathrm{Na}$ tym jednak ich wpływ się nie kończy: oddziałują one również na projekt badania czy kształt prototypu, kierowanie go do określonych grup użytkowników wraz z przypisywanymi im celami i cechami (por. Callon 2014b) czy też tworzenie i utrwalenie określonych technicznych standardów w danym sektorze. Jednocześnie, nawet jeśli oczekiwania wydają się skupione przede wszystkim na rozwoju technologicznym, są w nie wbudowane również przekonania dotyczące społecznej, ekonomicznej czy kulturowej przyszłości.

W ujęciu Konrad i współautorów oczekiwania wyłaniają się przede wszystkim w skutek agregacji rozporoszonych, celowych wysiłków różnych aktorów na rzecz tworzenia oczekiwań przez stosowanie technik antycy- 
pacyjnych i analitycznych takich jak foresighty, forecasty czy modelowanie (przegląd, zob. np. Halicka 2016, Stankiewicz 2015), ale również promowanie określonych oczekiwań przez konkretne grupy aktorów; również tych, którzy w nie inwestuja (a więc na przykład promocji wizji przyszłości z Teslą i Hyperloopem przez przedsiebiorcę Elona Muska). Oczekiwania moga być utrwalone nie tylko za pomocą raportów, ale również w materialnej formie prototypów, graficznej formie perswazyjnego schematu czy wykresu, czy też decyzji znaczących inwestorów, w przypadku których wsparcie konkretnych inicjatyw odczytać można jako przekonanie o prawdopodobnym przyszłym sukcesie danej technologii (Konrad i in. 2017: 467).

Zwracając uwage przede wszystkim na planowane, świadomie kształtowane oczekiwania, Konrad i współautorzy pozostawiaja poza polem widzenia co najmniej dwa istotne obszary wytwarzania i krążenia oczekiwań: proces kształtowania się oczekiwań poza centrami rozwoju technologicznego i gospodarczego, do których spływają oczekiwania wytworzone w centrum i podlegają specyficznym, nie zawsze dającym się zarządzać modyfikacjom; oraz stabilizowanie się oczekiwań jako procesu chaotycznego i przypadkowego raczej niż wynik technokratycznych i zdyscyplinowanych działań antycypacyjnych.

Dobrym przykładem wytwarzania oczekiwań związanych z rozwojem konkretnej technologii przez instytucje publiczne jest polski Plan Rozwoju Elektromobilności, zakładający, że samochody elektryczne staną się istotnym rozwiązaniem w transporcie osobowym i zbiorowym, a ich produkcja - ważnym sektorem polskiej gospodarki. Jednym z narzędzi do budowania wspólnych oczekiwań jest konkurs Electromobility Poland (http://konkurs.emobilitypoland.pl/), w ramach którego eksperci i szeroka publiczność wybierać maja projekt przyszłego polskiego e-samochodu. Jakkolwiek z oczekiwań związanych z rozwojem tej technologii można wyinterpretować niewypowiedziane założenia dotyczące roli gospodarki, polityki czy kultury, są one skupione na konkretnym rozwiązaniu - nie podejmują tematu zmian szerszych praktyk, na przykład wizji miast wolnych od smogu czy rozpowszechnienia wspólnego użytkowania auta.

Innym ciekawym obszarem kształtowania i wzmacniania oczekiwań związanych z technologiami przyszłości - tym razem przez aktorów z sektora prywatnego - jest finansowanie społecznościowe. Przyciagnięcie uwagi potencjalnych wspierających, mediów branżowych, a w konsekwencji inwestorów dysponujących znacznymi środkami zależne jest od tego, na ile proponowany produkt wpisuje się w oczekiwania dotyczące rozwoju danej technologii (Stasik 2018). Udana kampania crowdfundingowa musi odno- 
sić się do podzielanych przez wspierających oczekiwań, ale też je wzmacnia - popularność projektu staje się kolejnym argumentem na rzecz prawdopodobieństwa określonej wersji przyszłości.

Jednocześnie crowdfunding, podobnie jak inne konteksty poszukiwania środków finansowych, czy szerzej - mobilizowania sojuszników, stwarza też wyraźną pokusę strategicznego kształtowania nadmiernych oczekiwań, co może przynieść efekt hype’u, a na kolejnym etapie wieść do rozczarowania. Choć teorie dotyczące hype'u (w tym sławnego cyklu Gartnera) sa używane w pierwszej kolejności przez praktyków, stają się też przedmiotem studiów badaczy społecznych (por. np. Bakker, Budde 2012). Pierre-Benoit Joly zwracał uwagę na niedostatki porządku tworzenia technologii w coraz większym stopniu uzależnionego od wytworzenia hype'u - obietnicy przełomu i wstrząsu, jaki przynieść ma nowe rozwiązanie (Joly 2010). Proponował, by zastapić go porządkiem zbiorowego eksperymentowania, w którym rezygnujemy z figury heroicznego innowatora na rzecz wspólnej pracy nad rozwiązaniami, które mogą być modyfikowane i dostosowywane do różnych potrzeb i kontekstów, na wzór tworzenia oprogramowania opartego na otwartym kodzie źródłowym (por. Felt, Wynne 2007: 24-30). Postulat odejścia od rozumienia przyszłego rozwoju technologii jako wymagającego nadmiernych obietnic nie oznacza tylko zmiany retorycznej, ale też zmianę praktyk prowadzenia i wspierania (również finansowego) badań i rozwoju: wymaga utworzenia nowych wyobrażeń i nowych instytucji.

Wytwarzanie oczekiwań dotyczących technologii w porządku, który wymaga hype'u, często łączy się z nadzieją na technologiczną naprawę (ang. technological fix) palących problemów społecznych czy cywilizacyjnych. Co ciekawe, termin ten został wprowadzony i wypromowany w Stanach Zjednoczonych przez Alvina Weinberga (1966) jako odpowiedź na radziecką propozycję „inżynierii społecznej” (za: Stilgoe, Guston 2017: 859-860). Pomimo końca zimnej wojny i kolejnych zmian kulturowych idea rozwiazania złożonych kwestii politycznych i społecznych za pomocą technicznych interwencji nie odeszła $\mathrm{w}$ zapomnienie; pojawia się między innymi w debacie o zapobieganiu zmianom klimatu (por. Bińczyk 2015), ale również - jako rozwiązanie większej liczby problemów - w ideologii Doliny Krzemowej.

Od pojęcia oczekiwań, które koncentrują się na pojedynczej technologii - takiej jak elektryczny samochód czy wykorzystująca energię Słońca ładowarka do smartfonu promowana na platformie crowdfundingowej Konrad i współautorzy proponują odróżnić pojęcie wizji, rozumianej jako 
wiązka rozwiązań technologicznych mających przybliżać czy też umożliwiać pewną wizję przyszłego świata. Tutaj przykładem może być idea „Smart City”, wizja społeczności opartych w pełni na energii odnawialnej - na przykład sformułowana przez Jeremy’ego Rifkina (2011) - czy „Przemysłu 4.0" korzystającego z postępów w technologiach informatycznych. To rozróżnienie może być przydatne, ponieważ pozwala zauważyć, że projektowane artefakty - takie jak powszechnie wykorzystywany samochód elektryczny - mogą być elementami różnych wizji i zmieniać swoje znaczenie w zależności od kontekstu czy też sieci aktorów, w której funkcjonują. Oczekiwania dotyczące upowszechnienia elektrycznych samochodów często funkcjonuja jako element wizji „,zielonego wzrostu”, konsumpcyjnej gospodarki o znacznie ograniczonym zużyciu paliw kopalnych, ale w Polsce ich planowana masowa produkcja ma raczej wzmocnić i utrwalić dominację państwowych firm energetycznych korzystających z węgla, zapewniając im dodatkowe źródło zbytu w obliczu ,zagrożenia” związanego z rosnącą efektywnością energetyczna. Obserwacja tego rodzaju modyfikacji pozwala na podjęcie szerszego tematu: badania konkurujących i zmiennych wizji jako wytworów dłuższych przebiegów kultury czy też jako propozycji rozwijanych przez ruchy społeczne i polityczne. O ile oczekiwania związane z konkretnym produktem kształtowane sa przez technokratyczne działania antycypacyjne i działania promocyjne tych, którzy chcą na nich zarobić, o tyle polityczny wymiar wizji jest bardziej jawny. W konsekwencji istotniejszy jest wkład ruchów społecznych i intelektualistów. Zwycięskie wizje moga stać się elementem agendy politycznej. Wśród przykładów z przeszłości możemy przywołać na przykład wielka wizję powszechnej elektryfikacji (Hughes 1993). Szczególnie kiedy określona wizja przyszłości osiagnie status dominującego, niekontestowanego, oficjalnego kierunku rozwoju - współczesny przykład to Energiewende w Niemczach - może z powodzeniem wspierać koordynację działań aktorów z różnych sektorów.

Ostatnią forma performatywnych wizji przyszłości dyskutowaną przez Konrad i współautorów są imaginaria społeczno-technologiczne (ang. sociotechnical imaginaries) - pojęcie zaproponowane przez Sheilę Jasanoff i Sang-Hyun Kim (Jasanoff, Kim 2009, 2015). W tym ujęciu uwaga badaczki skupia się na tym, w jaki sposób wspólnotowe wyobrażenia porządku społecznego znajdujące odzwierciedlenie w projektach nauki i technologii, w tym również wielkie narracje o przyszłości, otwierają określone możliwości i wpływają na kształt, jaki ostatecznie przyjęły dane technologie. Imaginaria społeczno-technologiczne często badane sa na poziomie państwa narodowego - pozwalaja połączyć określone trajektorie rozwoju technologii 
z lokalnym rozumieniem wspólnoty, państwa i ładu społecznego. W ramach tej agendy badawczej można na przykład porównywać kształt transformacji energetycznej w różnych krajach i regionach świata, uwzględniając nie tylko warunki naturalne, infrastrukturalne czy kapitałowe, ale również wyobrażenia o tym, w jaki sposób może i powinna działać zbiorowość.

Proponowane rozróżnienie uwrażliwia na procesy, za pomocą których dyskursy, obiekty i działania mające przepowiadać przyszłość - tworzone za pomoca wielu języków i narzędzi, od poezji i science fiction, przez prototypy i zmiany w infrastrukturze, aż po raporty i decyzje inwestycyjne - wpływają na rozwój technologii i społeczeństwa. Naukowcy, wynalazcy i inżynierowie w swoich laboratoriach i firmach nie są w stanie działać w oderwaniu od oczekiwań, wizji i wyobrażeń - nawet jeśli podchodza do nich z dystansem, zmuszeni są do nawigowania w oceanie oczekiwań, jeśli chca zmobilizować konieczne zasoby i sojuszników. W ten sposób wspólnie wytwarzane przyszłości są jednym z czynników wpływających na to, jaki kształt przyjmą działania podjęte przez naukowców, inżynierów, wynalazców podczas konstruowania faktów i urządzeń budujących przyszły świat. Wyobrażane przyszłości są zatem zasobem służącym do modulowania wytworów nauki i techniki. O ile jednak wpływ naszych wyobrażeń na uzyskane jutro i pojutrze wyniki i artefakty jest złożony i trudny do przewidzenia, o tyle bezpiecznie możemy stwierdzić, że poruszające wizje przyszłości - te, które straszą, i te, które daja nadzieję - oddziałuja bezpośrednio na dzisiejsze wybory. Jeśli traktuję zagrożenie zmianami klimatu z należyta powaga, zmieniam swoje dzisiejsze praktyki, a jako wynalazczyni i innowatorka poszukuję rozwiązań, które pozwolą wyskalować korzystne zachowania. Nie oznacza to wcale, że zapobiegnę zmianom klimatu, a więc że wywrę oczekiwany skutek na przyszłościach - dziś jednak działam inaczej, niż gdybym nie podzielała tej wizji przyszłości.

Czy proponowane rozumienie sprawczości (wyobrażeń) przyszłości może pomóc w realizacji praktycznego postulatu STS, jakim jest bardziej przejrzyste i inkluzywne podejmowanie decyzji dotyczących kierunku rozwoju nauki i technologii? Żeby odpowiedzieć na to pytanie, trzeba przyjrzeć się różnym praktykom i technikom „przepowiadania” społeczno-technologicznych przyszłości.

\section{/// Wspólne wytwarzanie wizji}

Jeśli różne formy wyobrażania przyszłości mają istotny wpływ na nasze praktyki dzisiaj, a poprzez nie - może i na kształt świata jutra - pozosta- 
je zadać pytanie, z jakimi adekwatnymi formami zarządzania tymi przyszłościami warto eksperymentować. Chociaż próby naukowych sposobów przewidywania przyszłości sięgają korzeniami czasu narodzin nowoczesnej, Newtonowskiej nauki, a więc kształtowania się nauki o prawdopodobieństwie i nowoczesnego pojęcia (obliczalnego) ryzyka (Stilgoe, Guston 2017: 475, por. Stasik 2014), w tych rozważaniach skupię się na społecznych praktykach antycypowania rozwijanych po II wojnie światowej.

Przydatnym tłem do tych rozważań są badania Barbary Adam oraz Chrisa Grovesa (2007, zob. też Adam 2010), skupiające się na analizie tego, jak przyszłość jest opowiadana w różnych kulturach i czasach. Autorzy pokazuja, w jaki sposób modele opowiadanej przyszłości umożliwiaja określone działania: w tym szczególnie kolonizację przyszłości za pomocą działań rynkowych, naukowych i technologicznych (Adam 2010: 165-167). W kontekście różnych technik przepowiadania/przewidywania przyszłości szczególnie inspirujące jest rozróżnienie na przyszłość abstrakcyjna, zdeterminowaną mechanicystycznie, która wypełnia się jako realizacja niezmiennych, poznawalnych praw; przyszłość pusta, na którą składają się scenariusze obliczane za pomocą modelowania albo narzędzi, takich jak analiza zysków i korzyści; i wreszcie przyszłość otwartą, która określana jest przez projekty polityczne (w tym utopie), a więc w której - w przeciwieństwie do dwóch poprzednich - może dojść do głosu polityka czy aktywność ruchów społecznych. By użyć przykładów, przyszłość abstrakcyjną określa na przykład prawo Moore’a dotyczące tempa rozwoju technologii; przyszłość pustą - prognoza dotycząca zużycia zasobów naturalnych; przyszłość otwarta to przyszłość świata postwzrostu.

Każdy z tych modeli przyszłości jest powiązany z określonymi praktykami jej opisywania, ale też ramami normatywnymi i modelami sprawczości - podpowiada, jakiego rodzaju działania są pożądane, racjonalne, odpowiedzialne, możliwe. Szczególnie model przyszłości abstrakcyjnej i pustej obiecuje przewidywalność i kontrolę oraz możliwość zarządzania ryzykiem. Współkształtują one zatem różne formy wspólnego życia i determinują przeżywanie przyszłości w teraźniejszości. W kontraście do modeli, których podstawową funkcja jest danie nadziei kontroli i porządkowanie działań, Adam i Groves wprowadzają też termin ,żywa przyszłość” (ang. living future), „przyszłość w produkcji”, wytwarzana przez złożone interakcje, której realna złożoność zawsze umyka planom i której ostatecznie nie da się do nich zredukować.

Silny rozkwit przewidywania opartego na modelu pustej przyszłości ulokować można w okresie wojennym i powojennym w Stanach Zjedno- 
czonych $^{4}$, gdzie instytucje wojskowe i rządowe rozwijały podejścia ilościowe, takie jak analiza kosztów i korzyści czy symulacje oparte na teorii gier (Konrad i in. 2017: 476). Chociaż przewidywania oparte na ścisłych metodach i wiedzy eksperckiej były cenione, wkrótce pojawił się alternatywny sposób zaglądania do przyszłości, gdzie wytwarzane scenariusze miały nie tyle służyć przewidywaniu, ile stać się narzędziem kształtowania przyszłości przez identyfikację pożądanych opcji oraz działań, które moga prowadzić do ich realizacji. Tworzenie scenariuszy do dziś służy realizacji podobnych celów (por. Amer i in. 2013). Co więcej, już w latach 50. pojawiło się wezwanie do szerszego otwarcia procesu konstruowania przyszłości na głosy zróżnicowanych aktorów (Konrad i in. 2017: 476, Jungk, Galtung 1969) oraz eksperymenty instytucjonalne, które miały służyć realizacji tego celu. Wezwanie do oparcia procesów tworzenia przyszłości na mechanizmach partycypacyjnych i emancypacyjnych, które ostatnio ponawiał m.in. John Urry (2016), nie jest zatem nowe. Przewidywanie rozwoju technologii i jej społecznego wpływu miało zawierać zatem elementy „przyszłości otwartej”, kształtowanej z użyciem pragnień i wyobraźni. Jednak pomimo tych wczesnych eksperymentów badacze wskazuja, że od lat 70 . nad optymizmem dotyczącym przyszłości - także w wymiarze rozwoju technologicznego - zaczyna dominować pesymizm i ostrożność. Zinstytucjonalizowane antycypowanie przyszłości coraz bardziej koncentruje się na uniknięciu zagrożeń, przede wszystkim związanych bezpośrednio z (fizycznym) bezpieczeństwem oraz ze stratami ekonomicznymi. Na tym skupiają się najpowszechniejsze formy oceny technologii, opierające się na modelu pustej przyszłości, takie jak analiza ryzyka (ang. risk analysis $-\mathrm{R} A$ ), analiza korzyści i strat (ang. cost-benefit analysis - $C B A$ ), ocena technologii (ang. technology assessment - TA). Mimo że niewattpliwie użyteczne - i wciąż powszechnie stosowane - podejścia te mają również istotne ograniczenia. Oparcie się wyłącznie na metodach skupionych na fizycznym bezpieczeństwie i analizie ekonomicznej wyrzuca poza nawias debaty istotne kwestie dotyczące na przykład ekonomii politycznej, podziału zysków i korzyści pomiędzy różne grupy i w różnych horyzontach czasowych czy też kwestie symboliczne i związane z tożsamością i ugruntowaną kulturowo relacją na przykład do ciała ludzkiego czy do przyrody.

\footnotetext{
${ }^{4}$ Przedstawiona tu krótka historia przepowiadania nowoczesnych przyszłości skupiona jest - być może nadmiernie - na Stanach Zjednoczonych ze względu na dostępność piśmiennictwa i ograniczenie miejsca. Ciekawie byłoby sprawdzić, jakie modele przyszłości rozwijane były na użytek polityki - życia razem - pod drugiej stronie żelaznej kurtyny, w tym w Polsce.
} 
Odpowiedzią na dostrzeżone ograniczenia, uwidocznione przez kryzysy, takie jak odrzucenie w Europie żywności opartej na modyfikacjach genetycznych czy też konflikty wokół infrastruktury energetycznej (Stasik 2015b), jest próba rozwijania podejścia, które ma pozwolić nie tyle na społeczne zarządzanie ryzykiem, ile na społeczne zarządzanie tworzeniem innowacji, oparte na rozpoznaniu, że wypowiadając się o pożądanym kształcie innowacji, mówimy jednocześnie o kształcie społeczeństwa (por. Felt, Wynne 2007). Te próby instytucjonalizacji zakładają konieczność wsłuchiwania się w potrzeby i oczekiwania społeczne w procesie prowadzenia badań i projektowania, przy uwzględnieniu ich zróżnicowania oraz wielowymiarowości. Przykładem może być konstruktywna ocena technologii (ang. Constructive Technology Assessment), projektowanie wrażliwe na wartości (ang. Value Sensitive Design) czy konferencje konsensualne (por. Dryzek, Tucker 2008, Stasik 2015a, Dignum i in. 2016). Wśród stosowanych technik znajdziemy wspólną pracę nad rozwojem scenariuszy społeczno-technologicznych, prototypowanie, ale też dyskusje z użyciem kart do gry, opowiadanie historii alternatywnych, wycieczki po mieście połączone z planowaniem - cały szereg rozwiązań, które usiłują uwzględniać materialny wymiar projektowanych przyszłości.

Proponuję określać te działania jako „partycypację technokratyczna”, ponieważ techniki te z jednej strony wcielają w życie postulat szerszego korzystania z wiedzy, wyobraźni i wartości nie-ekspertów, z drugiej zaś - nie pozwalaja na zbudowanie i wprowadzenie w życie wizji technologicznych przyszłości niezgodnych z dominującą logiką. Ostatecznie często dążą do wprowadzenia niewielkich korekt, które maja umożliwić szeroką akceptację rozwiązań rozwijanych w laboratoriach. Badacze związani z STS byli szczególnie zaangażowani w podobne działania wokół nanotechnologii (zob. np. Felt, Schumann, Schwartz 2015, Felt, Schumann, Schwartz, Strassnig 2014, Bińczyk, Stępień 2014).

Kolejnym krokiem w stronę wspólnie wyobrażanej przyszłości jako zasobu do sterowania rozwojem nauki jest uwzględnienie dyskusji toczonych w czasie zgromadzeń hybrydowych (Callon, Lascoumes, Barthe 2009, por. Stasik 2015b, Lis, Stasik 2017). Ta propozycja ma tę zaletę, że nie ogranicza się do zaprojekowanych, technokratycznych form partycypacji, ale postuluje włączenie powstających spontanicznie konkurujących wizji przyszłości jako zasobu, a nie przeszkody, pomimo że często oznacza to konieczność zwolnienia tempa wprowadzania kolejnych rozwiązań. Tym samym jest w większym stopniu otwarta na społeczną samoorganizację i współpracę z ruchami społecznymi - a ostatecznie na odnoszenie rozwijanych techno-

\section{/ 168 STANRZECZY 1[14]/2018}


logii do otwartych przyszłości, w której jest miejsce na dyskusje polityczne i na perspektywę utopii.

Nieco inną odpowiedzią na dostrzeżenie intymnego związku nauki, technologii i przyszłości jest program „Odpowiedzialnej Nauki i Innowacji" (and. Responsible Research and Innovation - RRI). RRI jest podejściem silnie zinstytucjonalizowanym w europejskich politykach na rzecz nauki i badań, szczególnie w ramach programu Komisji Europejskiej „Nauka w Społeczeństwie” (ang. Science in Society) w kontekście Horyzontu 2020. Jakkolwiek dyskusja o odpowiedzialności nauki ma długą historię - do przełomowych wydarzeń w tej debacie można zaliczyć refleksje po projekcie Manhattan i niesławne badanie Tuskagee, w ramach którego dopuszczono do śmierci nieświadomych afroamerykańskich uczestników eksperymentu - pojęcie „odpowiedzialnego rozwoju i innowacji” w używanym obecnie znaczeniu zaczęło się kształtować w połowie lat dwutysięcznych; przypieczętowaniem instytucjonalizacji tego pola badań, refleksji i aktywności jest powstanie w 2014 roku pisma ,Journal of Responsible Innovation" (Stilogoe, Guston 2017: 855). RRI w znacznym stopniu pozostaje pod wpływem inspirowanego STS postulatu większego zaangażowania społeczeństwa we współdecydowanie o nauce, a także doświadczenia z partycypacyjnymi formami oceny technologii. Uznaje się, że społeczeństwo powinno mieć głos w dyskusji o przyszłości nauki i technologii - o tym, w jaki sposób należy ją rozwijać, tak żeby najlepiej służyła wspólnym celom i realizowała wspólne wartości. Jak wyraził to Morten Østergaard, duński Minister Nauki i Edukacji, dzięki RRI nauka rozwijana na Europejskim Obszarze Badawczym ma być nie tylko „najlepsza na świecie”, ale też „najlepsza dla świata" (za: Owen, Macnaghten, Stilgoe 2012: 752). Zgodnie z postulatem formułowanym między innymi w raporcie „Taking European Knowledge Society Seriously" (Felt, Wynne 2007) społeczna i polityczna dyskusja o rozwijaniu innowacji nie ma już być ograniczona wyłącznie do kwestii bezpieczeństwa, ale uwzględniać ma również pytanie o to, jaki jest cel nowego rozwiązania, kto na nim skorzysta, w jakim kierunku zmieni wspólnie zamieszkiwany świat.

W ramach RRI stosunek do przyszłości w kontekście nauki i technologii wypracowany w ramach STS zyskał zaskakująco duży wpływ i zasięg; o ile zaangażowanie opinii publicznej we współdecydowanie budzi czasem opór, o tyle trudno jawnie sprzeciwiać się odpowiedzialnym innowacjom (Guston 2015). Jednocześnie daje się zauważyć ambiwalencję obecna w niemal wszystkich projektach mających zaangażować opinię publiczna we współdecydowanie (por. Stankiewicz, Stasik, Suchomska 2015) - pew- 
ne wypowiedzi i praktyki wskazują, że główną motywacją decydentów jest zapobieżenie mobilizacji opinii publicznej przeciwko wprowadzaniu określonych rozwiązań. Innymi słowy, zaangażowanie opinii publicznej ma ułatwić zarządzanie ryzykiem politycznym i biznesowym, jakim jest odrzucenie rozwijanych technologii przez wczesne wykrycie potencjalnych punktów zapalnych.

\section{/// Podsumowanie}

Studia nad nauka i technologią mają istotny wkład w rozumienie relacji pomiędzy narracjami o przyszłościach a rozwojem innowacji. Po pierwsze, pokazują performatywny wymiar wyobrażanych wspólnie przyszłości społecznych czy społeczno-technologicznych: jakkolwiek przyszłość nie jest obiektem, który może być obserwowany i opisywany, w procesie wytwarzania innowacji jest niezbędnym zasobem do mobilizowania sojuszników w formie obietnicy lub przestrogi, oczekiwania czy wizji. Ze względów przede wszystkim normatywnych, ale do pewnego stopnia instrumentalnych badaczki z dziedziny studiów nad nauką i technologia namawiaja, by podjać wysiłek na rzecz demokratyzacji procesów tworzenia tych wizji. Ten normatywny postulat pozwala spojrzeć na praktyki antycypacji z innej perspektywy: oceniać je nie przez pryzmat trafności ani nawet tego, do jakiego stopnia pozwolą nam dostrzec potencjalne możliwości, ale jako kolejne narzędzie pozwalające sprecyzować, kim jesteśmy dzisiaj. Krytyczne, włączające działania na rzecz projektowania przyszłych technologii przede wszystkim mówią, co chcemy robić i jak działać - budują naszą teraźniejszość i świadczą o niej. Każda z prób uruchomienia procesów wyobrażania sobie przyszłości, które włączają różnorodne głosy, wpływa na to, kim jesteśmy teraz, udziela na nowo odpowiadzi na pytanie Bruno Latoura: „ilu nas jest i czy możemy razem żyć?” (2009). Jeśli wspólne wyobrażanie sobie przyszłości pozwoli lepiej zrozumieć dzisiejsze cele i wartości, to może w istocie wpłynąć na to, którą z przyszłości powołamy do życia. Włączające przewidywanie i prognozowanie ma zatem uruchamiać proces refleksyjności.

Trzeba przy tym pamiętać, że chociaż wraz z instytucjonalizacją RRI na Europejskim Obszarze Badawczym proponowane przez STS refleksyjne podejście do rozwoju innowacji zyskało szeroki zasięg, próby toczenia refleksyjnych debat i przekładanie ich wyników na decyzje polityczne sa marginalne wobec dominujących praktyk, w tym wzrastającej roli przewi- 
dywania w oparciu o Big Data i czarne skrzynki samouczących się algorytmów. Pominięcie w refleksji i praktyce roli mechanizmów rynkowych oraz ustabilizowanych interesów wpływających na (nie)tworzenie pewnych rozwiązań wydaje się jedną z największych luk w bieżącej dyskusji o refleksyjnym wytwarzaniu narracji o przyszłości. O ile można zrozumieć, że przyjęty punkt wyjścia wynikał z chęci poszerzenia dyskusji o innowacjach poza domenę rynku, o tyle unikanie tego wymiaru prowadzi do bezradności w obliczu najpoważniejszego wyzwania: w jaki sposób sprawić, żeby innowacje rozwijane od początku do końca w korporacyjnych laboratoriach również wcielały cele i wartości społeczeństw, którym mają służyć? Bez lepszego zrozumienia dynamiki innowacji w sektorze prywatnym i zastosowania odpowiednich narzędzi regulacyjnych RRI nie przyniesie adekwatnej odpowiedzi na problem, który diagnozuje.

Ujawnia to kolejny problem. Postulat społecznego współzarządzania rozwojem nauki i technologii jest radyklany - sprzeciwia się zarówno pewnemu rozumieniu autonomii nauki, jak i logice rynku. Omawiane praktyki antycypacyjne (takie jak konstruktywna ocena technologii) czy RRI próbują urzeczywistnić ten radykalny postulat za pomocą technokratycznych środków w ramach istniejącego systemu rynkowego i biurokratycznego. Tymczasem wydaje się, że społeczeństwo może wywrzeć wpływ na innowacje nie wtedy, kiedy uczestniczy w warsztatach zorganizowanych przez unijnych urzędników, ale kiedy mobilizuje się za lub przeciwko określonej wizji rozwoju, z którym łączy się rozwój technologii. Ciekawym przykładem takiej mobilizacji jest opór przeciwko niektórym technologiom energetycznym - wydobyciu gazu łupkowego (Stasik 2017, Cantoni, Lis, Stasik 2017), elektrowniom atomowym (Stankiewicz 2016, 2018) czy wydobyciu węgla brunatnego; ale również mobilizacja na rzecz zielonej transformacji (Seyfang, Haxeltine 2012). Napięcie pomiędzy dopuszczeniem społeczeństwa do głosu a uciszaniem i blokowaniem bardziej sprawczych, niezależnych, wojowniczych form, w których sprzeciw może się wyrazić, pozostaje istotną kwestią w badaniach nad nowymi formami partycypacji.

Wreszcie, dostrzeżenie roli dzisiejszych (wyobrażeń) przyszłości pozwala postawić pytanie o odpowiedzialność „futurystów”, których działania analizują badacze z nurtu STS - tych, którzy biorą na siebie zadanie opowiadania o wspólnych przyszłościach w językach nauki, publicystyki, sztuki czy popkultury. Jeśli wyobrażone przyszłości są zasobem, który pozwala ja kształtować, to tworzenie wizji przyszłości otwartej na horyzont utopii staje się jeszcze ważniejsze. 
Bibliografia:

/// Abriszewski K. 2008. Poznanie, zbiorowość, polityka. Analiza teorii aktora-sieci Bruno Latoura, Towarzystwo Autorów i Wydawców Prac Naukowych Universitas.

/// Adam B., Groves Ch. 2007. Future Matters: Action, Knowledge, Ethics, Brill.

/// Adam B. 2010. Czas, tłum. M. Dera, Wydawnictwo Sic!

/// Amer M., Daim T. U., Jetter A. 2013. A review of scenario planning, „Futures", nr 46, s. 23-40.

/// Bakker S., Budde B. 2012. Technological hype and disappointment: lessons from the bydrogen and fuel cell case, „Technology Analysis \& Strategic Management”, nr 24(6), s. 549-562.

/// Bińczyk E. 2007. Nie ma społeczeństwa! „Nasi mniejsi bracia” - społeczne studia nad nauka oraz etyczne zaangażowanie Bruno Latoura, „Teksty Drugie”, nr 1-2, s. 122-156.

/// Bińczyk E. 2012. Technonauka w społeczeństwie ryzyka. Filozofia wobec niepożqdanych nastepstw praktycznego sukcesu nauki, Wydawnictwo Naukowe Uniwersytetu Mikołaja Kopernika.

/// Bińczyk E. 2015. Monitorowanie technologii a nieusuwalne granice sterowalności (na proyktadzie krytyki projektu inżynierii klimatu), „Studia BAS - Biura Analiz Sejmowych", nr 3(43), s. 113-136.

/// Bińczyk E., Stępień T. 2014. Modeling Technoscience and Nanotechnology Assessment. Perspectives and Dilemmas, Peter Lang Edition.

/// Borup M., Brown N., Konrad K., Lente V.H. 2006. The sociology of expectations in science and technology, „Technology Analysis and Strategic Management", nr 18(3/4), s. 285-298.

/// Callon M. 2014a. Wprowadzenie do socjologii translacji. Udomowienie przegrzebków i rybacy znad zatoki Saint-Brienc, tłum. M.A. Chojnacka, [w:] Studia nad nauka i technologiq. Wybór tekstón, red. E. Bińczyk, A. Derra, Wydawnictwo Naukowe Uniwersytetu Mikołaja Kopernika, s. 289-330.

/// Callon M. 2014b. Spoleczeństwo w procesie tworzenia: badania technologii jako narzedzie analizy socjologicznej, tłum. R. Sojak, Studia nad nanka $i$ technologia. Wybór tekstón, red. E. Bińczyk, A. Derra, Wydawnictwo Naukowe Uniwersytetu Mikołaja Kopernika, s. 263-288. 
/// Callon M., Lascoumes P., Barthe Y. 2009. Acting in an uncertain world: an essay on technical democracy, tłum. G. Burchell, The MIT Press.

/// Dignum M., Correlje A., Cuppen E., Pesch U., Taebi B. 2016. Contested Technologies and Design for Values: The Case of Shale Gas, „Science and Engineering Ethics”, nr 22(4), s. 1171-1191.

/// Dryzek J.S., Tucker A. 2008. Deliberative Innovation to Different Effect: Consensus Conferences in Denmark, France, and the United States, ,Public Administration Review”, nr 68(5), s. 864-976.

/// Felt U., Wynne B. 2007. Taking European Knowledge Society Seriously. Raport of the Expert Group on Science and Governance to the Science, Economy and Society Directorate, \{Directorate-General\} for Research, European Commission.

/// Felt U., Schumann S., Schwarz C.G. 2015. (Re)assembling Natures, Cultures, and (Nano)technologies in Public Engagement, „Science as Culture”, nr 24(4), s. $458-483$.

/// Felt U., Schumann S., Schwarz C.G., Strassnig M. 2013. Technology of imagination: a card-based public engagement method for debating emerging technologies, „Qualitative Research”, nr 14(2), s. 233-251.

/// Fuller S. 2000. Thomas Kubn: A Philosophical History of Our Time, University of Chicago Press.

/// Guston D.H. 2015. Responsible Innovation: Who Could be against That?, ,Journal of Responsible Innovation", nr 2(1), s. 1-4.

/// Halicka K. 2016. Prospektywna analiza technologii. Metodologia i procedury badawcre, Oficyna Wydawnicza Politechniki Białostockiej.

/// Harari Y.N. 2018. Homo Deus. Krótkea historia jutra, tłum. M. Romanek, Wydawnictwo Literackie.

/// Hughes T. 1993. Networks of Power: Electrification in Western Society, 18801930, John Hopkins University Press.

/// Jasanoff S. 2004. Ordering knowledge, ordering society, [w:] tejże, States of Knowledge: the Co-Production of Science and Social Order, Routledge, s. 13-45.

/// Jasanoff S. 2016. The Ethics of Invention. Technology and the Human Future, Norton\&Co. 
/// Jasanoff S., Kim S.-H. 2009. Containing the Atom: Sociotechnical Imaginaries and Nuclear Power in the United States and South Korea, "Minerva”, nr 47, s. 119-146.

/// Jasanoff S., Kim S.-H. 2015. Dreamscapes of Modernity. Sociotechnical Imaginaries and the Fabrication of Power, The University of Chicago Press.

/// Joly P.-B. 2010. On the economics of techno-scientific promises, [w:] Débordements. Mélanges offerts à Michel Callon, red. M. Akrich, Y. Barthe, F. Muniesa, Ph. Mustar, Presses des Mines, s. 203-222.

/// Jungk R., Galtung J. 1969. Mankind 2000, Allen\&Unwin.

/// Konrad K., van Lente H., Groves Ch., Selin C. 2017. Performing and Governing the Future in Science and Technology, [w:] The Handbook of Science and Technology Studies. Fourth Edition, red. U. Felt, R. Fouche, C.A. Miller, L. Smith-Doerr, The MIT Press, s. 465-494.

/// Latour B. 1987. Science in Action. How to follow scientists and engineers through society, Harvard University Press.

/// Latour B. 2004. Which protocol for new collective experiments?, [w:] Experimental Cultures, red. H. Schmindgen, Kadmos Verlag, s. 17-36.

/// Latour B. 2005. From Realpolitik to Dingpolitik or how to make things public, [w:] Making things public. Atmospheres of democracy, red. B. Latour, P. Weibel, s. 4-32.

/// Latour B. 2009. Polityka natury, tłum. A. Czarnecka, Wydawnictwo Krytyki Politycznej.

/// Latour B. 2010. Splatajac na nowo to, co spoteczne. Wprowadzenie do teorii aktora-sieci, tłum. A. Derra, K. Abriszewski, Towarzystwo Autorów i Wydawców Prac Naukowych Universitas.

/// Latour B. 2011. Nigdy nie bylismy nowocześni, tłum. M. Gdula, Oficyna Naukowa.

/// Latour B. 2013. Technologia jako utrwalone społeczeństwo, thum. L. Afeltowicz, „AVANT”, nr IV(1), s. 17-48.

/// Lis A., Stasik A. 2017. Hybrid forums, knowledge deficits and the multiple uncertainties of resource extraction: Negotiating the local governance of shale gas in Poland, „Energy Research \& Social Science”, nr 28, s. 29-36. 
/// Owen R., Macnaghten P., Stilgoe J. 2012. Responsible research and innovation: From science in society to science for society, with society, ,Science and Public Policy", nr 39(6), s. 751-760.

/// Rifkin J. 2011. Træecia rewolucja przemysłowa, tłum. A. Olesiejuk, K. Różycka, Wydawnictwo Sonia Draga.

/// Seyfang G., Haxeltine A. 2012. Growing grassroots innovations: Exploring the role of community-based initiatives in governing sustainable energy transitions, „Environment and Planning C: Government and Policy”, nr 30(3), s. 381-400.

/// Sismondo S. 2008. Science and Technology Studies and an Engaged Program, [w: The Handbook of Science and Technology Studies. Third Edition, red. E.J. Hackett, O. Amsterdamska, M. Lynch, J. Wajcman, The MIT Press, s. 13-32.

/// Stankiewicz P. 2015. Klasyczna i partycypacyjna ocena technologii, „Studia BAS", nr 3(43), s. 13-34.

/// Stankiewicz P. 2018. Gra w atom. Spoleczne zarzqdzanie technologia w rozwoju energetyki jadrowej w Polsce, Wydawnictwo Naukowe Uniwersytetu Mikołaja Kopernika.

/// Stankiewicz P., Stasik A., Suchomska J. 2015. Od informowania do wspótdecydowania $i$ zpowrotem. Prototypowanie technologicznej demokracji, „Studia Socjologiczne", nr 3(218), s. 65-101.

/// Stasik A. 2014. Ocena oddriaływania technologii w erze niepewności-wyzwanie poznawcze jako wyzwanie polityczne, „Polityka Społeczna”, nr 41(5-6), s. 13-17.

/// Stasik A. 2015a. Jak prowadzić partycypacyjna ocene technologii? Praeglad metod i technik, „Studia BAS”, nr 3(43), s. 87-112.

/// Stasik A. 2015b. Ocena ryzyka i niepewności zwiazanych z. nowymi technologiami jako wyzwanie dla demokracji. Kontrowersje wokót wydobywania gazu tupkowego w Polsce. Manuskrypt rozprawy doktorskiej.

/// Stasik A. 2017. Global controversies in local settings: anti-fracking activism in the era of Web 2.0, „Journal of Risk Research", 1-17 (online first).

/// Stasik A. 2018. Zastosowanie crowdfundingu we wspieraniu innowacji w dziedzinie zielonej energii: przeglad praktyk oraz diagnoza potencjatu i barier, „E-mentor” (w druku). 
/// Stilgoe J., Guston D.H. 2017. Responsible Research and Innovation, [w:] The Handbook of Science and Technology Studies. Fourth Edition, red. U. Felt, R. Fouche, C.A. Miller, L. Smith-Doerr, The MIT Press, s. 859-860.

/// Urry J. 2016. What is the Future?, Polity Press.

/// Weinberg A. 1996. Can Technology Replace Social Engineering?, „Bulletin of the Atomic Scientists", nr 22(10), s. 4-8.

/// Wewiór P. 2017. Wstęujac w ślady Salomona. Religia i nauka w myśli Francisa Bacona, Wydawnictwo Naukowe Uniwersytetu Mikołaja Kopernika.

\section{/// Abstrakt}

Celem artykułu jest przeanalizowanie wkładu studiów nad nauką i technologią (STS) w debatę o dwustronnej zależności pomiędzy wytwarzaniem wiedzy i technologii a przyszłościami społecznymi i dzisiejszymi wyobrażeniami o możliwych przyszłościach. Przedstawiono kolejno podstawowe założenia STS, rozwijane w ramach tego nurtu rozumienie sprawczego działania wizji przyszłości na rozwój innowacji oraz techniki i procesy wytwarzania podzielanych wizji społeczno-technologicznych przyszłości: od partycypacyjnej oceny technologii, przez działanie ruchów społecznych, aż po próbę oficjalnego wbudowania odpowiedzialności wobec obywateli w politykę Europejskiego Obszaru Badawczego. W podsumowaniu formułowana jest propozycja poszerzenia programu badań nad dynamiką tworzenia sprawczych wyobrażeń o przyszłości o uwzględnienie dynamiki rynku, rolę grup interesu oraz ruchów społecznych.

Słowa kluczowe:

Studia nad nauka i technologią; odpowiedzialne badania i innowacje; przyszłość; innowacje; partycypacja; ocena technologii

\section{/// Abstract}

The paper analyzes the contribution of studies on science and technology (STS) to the debate on the relationship between science and technology, our today's ideas about possible futures (present futures), and the future to come as the results of our actions (future present). First, I present the basic assumptions of STS and how it frames the impact of the visions of the future on the innovations. Then, I review the processes leading 
to the creation of a shared socio-technological future: from participatory assessment of technology through social movements' engagement to the official policy of the European Research Area. I argue that STS research on societal futures should include market dynamics, the role of interest groups and social movements.

Keywords:

Science and technology studies; responsible research and innovation; future; innovation; participation; technology assessment

/// Agata Stasik - doktor socjologii, adiunkt w Katedrze Zarządzania w Społeczeństwie Sieciowym na Akademii Leona Koźmińskiego. Zajmuje się studiami nad nauką i technologią, badaniami nad innowacjami oraz społecznym zarządzaniem ryzykiem; szczególnie interesują ją technologie i systemy energetyczne. Zrealizowała pobyty badawcze na Uniwersytecie w Wiedniu oraz Uniwersytecie w Goteborgu. Publikowała m.in. w „Journal of Risk Research”, „Energy Research and Social Science”, „Studiach Socjologicznych", „Journal of Management and Public Administration: Central Europe".

Email: stasik.agata@gmail.com 